646

日本機械学会論文集 ( $\mathrm{C}$ 編)

76 巻 763 号 $(2010-3)$

論文 No.09-0637

\title{
不確かさをもつ劣駆動飛行船システムの 大域的ロバスト安定化と飛行実験*
}

\author{
山田学*1, 富 塚 誠 義*2

\begin{abstract}
Robust Global Stabilization of an Underactuated Airship with Parameter Uncertainties and Flight Experiments
\end{abstract}

\author{
Manabu YAMADA*3 and Masayoshi TOMIZUKA \\ ${ }^{* 3}$ Research Center for Nano Device and System, Nagoya Institute of Technology, \\ Gokiso-cho, Shouwa-ku, Nagoya-shi, Aichi, 466-8555 Japan
}

\begin{abstract}
This paper considers the problem of controlling both the planar position and the orientation of an underactuated airship with a reduced number of actuators. The airship is a nonholonomic system described by a set of nonlinear equations and the dynamics are subject to bounded uncertainties. A smooth and time-varying coordinate transformation is utilized to reduce the robust stabilization problem of the airship to that of a linear time-invariant system. A new robust feedback controller is obtained for global stabilization of both the position and the orientation of the underactuated airship with parameter uncertainties. The proposed design method is simple and straightforward. Experiments are performed to validate the effectiveness of the proposed controller.
\end{abstract}

Key Words: Autonomous Airship, Nonholonomic System, Nonlinear Control, Robust Control, Parameter Uncertainty, Global Stability, Flight Experiment, Moving Robot

\section{1. 緒言}

飛行船は他の航空機に比べて安全性が高く，長期飛 行，空中静止などニニークな利点をもつ(1)،（2). 近年， その特徵を活用し，例えば飛行船を人工衛星に代わる 通信中継基地に利用するプロジェクト(3)やレスキュ 一支援などが進められている，著者は，絰務省の戦略 的情報通信研究開発推進制度 (SCOPE) の委託研究の 下，ソーラー飛行船による情報通信プロジェクト(4) な どを実施している.これらの主要技術の一つとして， 飛行船の位置と姿勢の自動制御技術が必要とされる.

本稿では，水平平面内において，飛行船の位置およ び姿勢を制御する問題について考察する. 飛行船はコ リオリカなどの非線形項をもつ非線形システムであり， その状態方程式は船と同形である (2)。また，多くの飛 行船は船と同様，プロペラと舵が船体運動の制御手段 でありここれらにより船体の前後方向の力と回転モー メントを与えることはできるが，船体の横方向に直接 力を与えることができない(2),(5)，そのため，文献(6) で示されているように，このシステムは加速度に関し て不可積分な拘束，すなわち非ホロノミックな拘束を

\footnotetext{
* 原稿受付 2009 年 7 月 3 日.

*1 正員, 名古屋工業大学極微デバイス機能システム研究セン 夕一( (ङ 466-8555 名古屋市昭和区御器所町).

*2 正員, カリフォルニア大学バークレー校(Berkeley, CA 94720-1740 USA).

E-mail : yamada.manabu@nitech.ac.jp
}

もつ劣駆動機械系のの一つである.このような非ホ口 ノミックなシステムの制御の難しさは, 連続で静的な フィードバック則では安定化できない点である(8)．飛 行船や船などの劣駆動系の安定化制御手法に関しては, 船の制御問題を中心にこれまでに数多くの研究が報告 され，不連続フィードバックに基づいた方法 (6)，時変 フィードバックによる方法(9), Averaging に基づいた 方法 (10)，(11) など数多くの興味深い手法が提案されてい る. 著者ら(12)，(13) は，時変な座標変換に基づき，劣駆 動飛行船を大域的指数安定化する手法を提案し，実機 による飛行実験を実施し有効性を実証した．さらにこ の手法を応用し，速度情報を必要としないオブザーバ による安定化(14) も提案している. また最近では, Nesic らにより，実用上の観点からサンプル值制御問題につ いて考察され，非線形サンプル值系の離散時間近似モ デルによる手法(15)，(16) を利用して, 安定性を保証する連 続時間補償器の再設計法 (17) や Receding Horizon 制御 法 (18) が提案されている. しかしこれらの従来法では, 制御目標がシステムの安定化に限定されており，実用 上重要な飛行船の物理パラメーラの不確かさに対する システムのロバスト性が考慮されていない.

本稿では，実用上の観点からロバスト制御問題につ いて考察する. 飛行船や船などの劣駆動機械系のロバ スト制御に関寸る研究の報告例は, Do らの手法 (19),(20) など数少ない，しかもこの手法は追従制御のみで，追 
従可能な目標値は一定速度（非零）で移動する直線軌 道などに限定されており，希望の位置·姿勢老達成し， 定点滞空させる安定化問題は扱われていない．

本稿では，速度減衰係数などに不確かさをもつが範 囲は既知である劣駆動飛行船システムのロバスト安定 化問題について考察し, 座標变換と 2 次安定化制御 (21) に基づいた新しい手法で，大域的ロバスト安定化制御 系の設計法を提案する. 本研究の利点は以下の通りで ある．第一に，提案する制御系は不確かさをもつ劣駆 動非ホロノミック系に対してロバスト安定性を保証し， どんな初期状態からでも任意の希望の位置と姿勢を達 成し定点滞空できる. 第二に, 速度減衰係数などに不 確かさをもつが範囲は既知である劣駆動飛行船システ 厶を, quadratic bound method ( $\mathrm{QB}$ 法) (22) と時変な 座標変換を導入することにより, 劣駆動系のロバスト 安定化制御問題を, ある可制御な線形時不変系の標準 的な 2 次安定化問題 (21) に帰着させ設計を簡単化する. その結果, システムのロバスト安定化の可能性を，あ るリカッチ不等式の可解性で明確から簡単に判定でき, その解を用いてロバスト補償器を容易に設計できる. 第三に，提案する座標変換はシステムの状態や制御入 力に依存しないため, 特異点を完全に回避し大域的指 数安定性を保証できる.この座標変換は機体座標系に おける横方向の位置と速度に重みを掛けているため, まず劣駆動飛行船の横方向の位置を優先的に希望值に 收束させ，その後，姿勢角之進行方向の位置を希望值 に収束させ，切り返し動作を含む動きで安定化できる (12)-(14)，第四に，提案寸る制御系は滑らかで特異点の ない座標変換と状態フィードバック補償器で構成され, 実装は容易である. 最後に, 小型飛行船を用いて自律 飛行制御実験を実施し，本手法の有用性を飛行実験に より実証する.

\section{2. 問題の定式化}

本稿では水平平面内において，二つの独立したプロ ペラで図 1 の飛行船の位置および姿勢を制御する問題

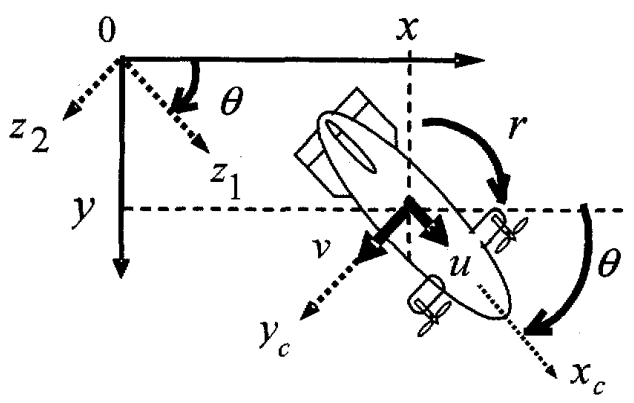

Fig.1 Model of underactuated airship
を考察する. $(x, y)$ は地上座標系における飛行船の重心 の位置を示す. $\theta$ は地上座標系における飛行船の姿勢 角を示す. $u, v, r$ 以機体座標系における前進速度, 横 方向速度，回転角速度を示寸，飛行船は左右対称であ り，飛行船の回転中心と重心は一致すると仮定する. 飛行船の運動の動的方程式は機体座標系において

$$
\begin{aligned}
& {\left[\begin{array}{ccc}
m_{1} & 0 & 0 \\
0 & m_{2} & 0 \\
0 & 0 & m_{3}
\end{array}\right]\left[\begin{array}{l}
\dot{u} \\
\dot{v} \\
\dot{r}
\end{array}\right]+\left[\begin{array}{ccc}
0 & 0 & -m_{2} v \\
0 & 0 & m_{1} u \\
m_{2} v & -m_{1} u & 0
\end{array}\right]\left[\begin{array}{l}
u \\
v \\
r
\end{array}\right]} \\
& +\left[\begin{array}{ccc}
d_{11} & 0 & 0 \\
0 & d_{22} & 0 \\
0 & 0 & d_{33}
\end{array}\right]\left[\begin{array}{l}
u \\
v \\
r
\end{array}\right]=\left[\begin{array}{c}
\tau_{u} \\
0 \\
\tau_{r}
\end{array}\right]
\end{aligned}
$$

と記述される(2), (12)。ただし， $m_{i}, i=1,2,3$ は慣性に関 する正の定数, $d_{i l}, i=1,2,3$ 汒速度減衰に関する正の定 数である. $\tau_{u}, \tau_{r}$ はプロペラによる機体進行方向の駆 動力と操舵卜ルクであり，これら2つが制御入力であ る.式(1)より横(左右)方向の推進力を持たないため, 考察するシステムは劣駆動系である.

地上座標系と飛行船の機体座標系の幾何学的関係 は

$$
\left\{\begin{array}{l}
\dot{x}=u \cdot \cos \theta-v \cdot \sin \theta \\
\dot{y}=u \cdot \sin \theta+v \cdot \cos \theta \\
\dot{\theta}=r
\end{array}\right.
$$

で与えられる.つぎの座標変換

$$
\left\{\begin{array}{l}
z_{1}=x \cdot \cos \theta+y \cdot \sin \theta \\
z_{2}=-x \cdot \sin \theta+y \cdot \cos \theta
\end{array}\right.
$$

を導入すると次式を得る。

$$
\left\{\begin{array}{l}
\dot{z}_{1}=u+z_{2} r \\
\dot{z}_{2}=v-z_{1} r
\end{array}\right.
$$

このとき飛行船システムは，回転方向成分のサブシ ステムを $\Sigma_{1}$, 並進方向成分のサブシステムを $\Sigma_{2}$ とお くと，式(1)と式(4)よりつぎのように表せる.

$$
\begin{aligned}
& \Sigma_{1}: \dot{x}_{1}(t)=A_{1} x_{1}(t)+b_{1} u_{1}(t)+f(t) \\
& x_{1}=\left[\begin{array}{l}
\theta \\
r
\end{array}\right], \quad A_{1}=\left[\begin{array}{cc}
0 & 1 \\
0 & -d_{3}
\end{array}\right], \quad b_{1}=\left[\begin{array}{l}
0 \\
1
\end{array}\right], \\
& d_{3}=\frac{d_{33}}{m_{3}}, \quad u_{1}=\frac{\tau_{r}}{m_{3}}, \quad f^{T}=\left[0, \frac{m_{1}-m_{2}}{m_{3}} u v\right]
\end{aligned}
$$

$\Sigma_{2}: \dot{x}_{2}(t)=A_{2}(r(t)) x_{2}(t)+b_{2} u_{2}(t)$ 


$$
\begin{aligned}
& \boldsymbol{x}_{2}=\left[\begin{array}{c}
u \\
v \\
z_{1} \\
z_{2}
\end{array}\right], A_{2}=\left[\begin{array}{cccc}
-d_{1} & \frac{m_{2}}{m_{1}} r & 0 & 0 \\
-\frac{m_{1}}{m_{2}} r & -d_{2} & 0 & 0 \\
1 & 0 & 0 & r \\
0 & 1 & -r & 0
\end{array}\right], \boldsymbol{b}_{2}=\left[\begin{array}{l}
1 \\
0 \\
0 \\
0
\end{array}\right] \\
& d_{i}=\frac{d_{i i}}{m_{i}}(i=1,2), u_{2}=\frac{\tau_{u}}{m_{1}}
\end{aligned}
$$

本稿では，速度减哀関する保数， $d_{i}, i=1,2,3$ が不確 かさをもち，次式で与えられるものとする.

$$
\underline{d}_{i} \leq d_{i} \leq \bar{d}_{i}, i=1,2,3
$$

ただし，下限值と上限值， $d_{i}, \bar{d}_{i},(i=1,2,3)$ は与えられた 正の実数とする. 次の問題について考える.

\section{【大域的口バスト安定化問題】}

式(7)を満たす任意の速度减衰係数と任意の初期状態に 対して式(5)之式(6)のシステムの原点を安定，すなわち状 態 $x_{1}(t) \in \mathbb{R}^{2}$ と $x_{2}(t) \in \mathbb{R}^{4}$ を全て零に収束させるフィー ドバック補償器 $u_{i}(t) \in \mathbb{R},(i=1,2)$ を求めよ.

\section{3. 準 備}

つぎの補助定理は，システムの安定化問題を解く際に利 用寸る。

\section{補助定理 1 (23), (24)}

つぎの線形時変システムにつて考える.

$$
\dot{x}(t)=(A+\Delta(t)) x(t), x \in \mathbb{R}^{n}
$$

ただし時変要素 $\Delta(t) \in \mathbb{R}^{n \times n}$ は次式を満たす。

$$
\lim _{t \rightarrow \infty}\|\Delta(t)\|=0, \int_{0}^{\infty}\|\Delta(t)\| d t<\infty
$$

このとき実定数行列 $A$ が安定行列（すなわち，行列 $A$ の固 有值の実部がすべて負) ならば，この時変システムは原点 に拈いて大域的指数安定である.

第一章で記載したように，本稿では不確かさをもつシス テムに対する安定性として「二次安定性」を用いる. その 定義は以下のとおりである.

\section{定義 (21)}

つぎの不碓かさをもつ線形時変システムについて考える.

$$
\dot{\boldsymbol{x}}(t)=A(s(t)) \boldsymbol{x}(t), x \in \mathbb{R}^{n}
$$

ただし $\boldsymbol{s}(t) \in \mathbb{R}^{m}$ は範囲が与えられた不確かさを表すパ ラメータベクトルとする. このとき適当な $\mathrm{n}$ 次の定数行列 $P>0$ と定数 $\mu>0$ が存在し，軌道 $\boldsymbol{x}(t)$ に沿った二次形式

$$
V(\boldsymbol{x})=\boldsymbol{x}(t)^{T} P \boldsymbol{x}(t)
$$

の時閒微分が，末知パラメータ $s(t) \in \mathbb{R}^{m}$ と無関係に

$$
\frac{d}{d t} V(\boldsymbol{x}) \leq-\mu\|\boldsymbol{x}\|^{2}
$$

を満たすとき：システムは一次安走であるという，

\section{4. 主結果}

$4 \cdot 1$ サブシステム $\Sigma_{1}$ のロバスト安定化 まず式 （7）の下で式(5)のサブシステムをロバスト安定化する ため，つぎのフィードバック補償器を考える.

$$
\left\{\begin{array}{c}
u_{1}(t)=\boldsymbol{f}_{1} \boldsymbol{x}_{1}(t)+\alpha e^{-q t}-\frac{m_{1}-m_{2}}{m_{3}} u v \\
f_{1}=-\left[k_{1} k_{2}, k_{1}+k_{2}-\underline{d}_{3}\right] \in \mathbb{R}^{2}
\end{array}\right.
$$

ただし， $\left[k_{1}, k_{2}, q, \alpha\right] \in \mathbb{R}^{4}$ は設計パラメータであり， 次式の条件の下で任意に選ぶ。

$$
0<q<k_{i} \quad(i=1,2), \quad \alpha \neq 0
$$

式(13)と式(14)を式(5)に代入すると，サブシステム $\Sigma_{1}$ は

$$
\left\{\begin{array}{l}
\ddot{\theta}(t)+\left(k_{1}+k_{2}+\Delta_{d}\right) \dot{\theta}(t)+k_{1} k_{2} \theta(t)=\alpha e^{-q t} \\
\Delta_{d}=d_{3}-\underline{d}_{3}
\end{array}\right.
$$

となる. ただし式(7)から

$$
0 \leq \Delta_{d} \leq \bar{d}_{3}-\underline{d}_{3}
$$

を満たす. 飛行船の姿勢角 $\theta$ と角速度 $r$ の応答は

$$
\begin{aligned}
& \left\{\begin{array}{l}
\theta(t)=\theta_{0} e^{-q t}+\sum_{i=1}^{2} \theta_{i} e^{-\lambda_{i} t} \\
r(t)=-q \theta_{0} e^{-q t}-\sum_{i=1}^{2} \lambda_{i} \theta_{i} e^{-\lambda_{i} t}
\end{array}\right. \\
& \theta_{0}=\frac{\alpha}{\left(q-\lambda_{1}\right)\left(q-\lambda_{1}\right)} \in \mathbb{R} \\
& \theta_{1}=\frac{\lambda_{2} \theta(0)+r(0)}{\lambda_{2}-\lambda_{1}}+\frac{\alpha}{\left(\lambda_{2}-\lambda_{1}\right)\left(q-\lambda_{1}\right)} \in \mathbb{R} \\
& \theta_{2}=\frac{\lambda_{1} \theta(0)+r(0)}{\lambda_{1}-\lambda_{2}}+\frac{\alpha}{\left(\lambda_{1}-\lambda_{2}\right)\left(q-\lambda_{2}\right)} \in \mathbb{R} \\
& \lambda_{1}, \lambda_{2}=\frac{\left(\Delta_{d}+k_{1}+k_{2}\right) \pm \sqrt{\Delta_{d}^{2}+2 \Delta_{d}\left(k_{1}+k_{2}\right)+\left(k_{1}-k_{2}\right)^{2}}}{2} \in \mathbb{R}
\end{aligned}
$$

と表される.さらに

$$
0<q<\frac{\left(\bar{d}_{3}-\underline{d}_{3}+k_{1}+k_{2}\right)-\sqrt{\left.\left(\bar{d}_{3}-\underline{d}_{3}+k_{1}+k_{2}\right)\right)^{2}-4 k_{1} k_{2}}}{2}
$$


と選べば，式(7)を満たす任意の $d_{3} に$ 詨して，次式が 成り立ち, 式(5)のシステムの原点は大域的指数安定で ある.

$$
0<q<\lambda_{i} \quad(i=1,2)
$$

\section{$4 \cdot 2$ サブシステム $\Sigma_{2}$ のロバスト安定化 つぎ} にサブシステム $\Sigma_{2}$ のロバスト安定化問題について考 える. 式(6)と式(17)より, サブシステム $\Sigma_{2}$ は時変要 素 $r(t)$ を持つ線形時変系である. つぎの時変な座標変 換 $\Lambda(t)$ を導入し，新たに状態 $\bar{x}_{2}(t)$ を定義する. この 座標変換は, 後述のように, 時変システム $\Sigma_{2}$ の安定 化問題を，ある可制御で線形時不変系の安定化問題に 帰着させ，設計を簡単化するだけでなく，飛行船の動 きについても切り返し動作を含さ運動制御を可能にす るもので, 本研究のキーポイントである.

$$
\begin{aligned}
\overline{\boldsymbol{x}}_{2}(t)=\Lambda(t) \boldsymbol{x}_{2}(t) \\
\Lambda(t)=\operatorname{diag}\left[1, e^{q t}, 1, e^{q t}\right] \in \mathbb{R}^{4 \times 4}
\end{aligned}
$$

ただし $q \in \mathbb{R}$ は，式(13)て設計者が与えたパラメータであ る. この座標変換を行うと, 式(6)の時変システムは

$$
\begin{aligned}
\dot{\boldsymbol{x}}_{2}(t) & =\left(\bar{A}_{2}+\Delta_{A}(t)\right) \overline{\boldsymbol{x}}_{2}(t)+\boldsymbol{b}_{2} u_{2}(t) \\
\bar{A}_{2} & =\left[\begin{array}{cccc}
-d_{1} & 0 & 0 & 0 \\
\frac{m_{1}}{m_{2}} \theta_{0} q & -\left(d_{2}-q\right) & 0 & 0 \\
1 & 0 & 0 & 0 \\
0 & 1 & \theta_{0} q & q
\end{array}\right] \\
\Delta_{A} & =\left[\begin{array}{cccc}
0 & \frac{m_{2}}{m_{1}} r(t) e^{-q t} & 0 & 0 \\
\frac{m_{1}}{m_{2}} a(t) & 0 & 0 & 0 \\
0 & 0 & 0 & r(t) e^{-q t} \\
0 & 0 & a(t) & 0
\end{array}\right] \\
a(t) & =-\left(\theta_{1} \lambda_{1} e^{-\left(\lambda_{1}-q\right) t}+\theta_{2} \lambda_{2} e^{-\left(\lambda_{2}-q\right) t}\right)
\end{aligned}
$$

と表せる. 式(19)から時変要素 $A_{A} \in \mathbb{R}^{4 \times 4}$ は定数項を 持たず零人指数収束する要素であり, 次式を満たす。

$$
\lim _{t \rightarrow \infty}\left\|\Delta_{A}(t)\right\|=0, \int_{0}^{\infty}\left\|\Delta_{A}(t)\right\| d t<\infty
$$

したがって, 補助定理 1 より題意のロバスト安定化問題は, 式(21)から時変要素 $\Delta_{A} \in \mathbb{R}^{4 \times 4}$ を除いたつぎの線形時不変 システムのロバスト安定化問題こ帰着される.

$$
\dot{\bar{x}}_{0}(t)=\bar{A}_{2} \bar{x}_{0}(t)+b_{2} u_{2}(t), \quad \bar{x}_{0} \in \mathbb{R}^{4}
$$

注意すべきは，行列 $\bar{A}_{2} \in \mathbb{R}^{4 \times 4}$ は定数行列であるが， $\left[d_{1}, d_{2}, \theta_{0}\right]$ を含み，構造的不碓かさを持つことである. そ こで $\mathrm{QB}$ 法(2)を用いて構造的不確力さのパラメータ表現 を行う.まず $\theta_{0} \in \mathbb{R}$ は式(17)より

$$
\theta_{0}=\frac{\alpha}{q^{2}-\left(\Delta_{d}+k_{1}+k_{2}\right) q+k_{1} k_{2}}
$$

であるため,

$$
\begin{aligned}
& \underline{\theta}_{0} \leq \theta_{0} \leq \bar{\theta}_{0},\left(0 \leq \Delta_{d} \leq \bar{d}_{3}-\underline{d}_{3}\right) \\
& \left\{\begin{array}{l}
\underline{\theta}_{0}=\left.\theta_{0}\right|_{\Delta_{d}=0}=\frac{\alpha}{\left(q-k_{1}\right)\left(q-k_{2}\right)} \\
\bar{\theta}_{0}=\left.\theta_{0}\right|_{\Delta_{d}=\bar{d}_{3}-\underline{d}_{3}}=\frac{\alpha}{q^{2}-\left(\bar{d}_{3}-\underline{d}_{3}+k_{1}+k_{2}\right) q+k_{1} k_{2}}
\end{array}\right.
\end{aligned}
$$

と表せる、したがって不確かさを浛な゚ラメー夕は

$$
\begin{aligned}
& d_{i}=d_{i 0}+\Delta_{i},\left|\Delta_{i}\right| \leq \delta_{i}, \quad i=1,2 \\
& \theta_{0}=\theta_{00}+\Delta_{0},\left|\Delta_{0}\right| \leq \delta_{0} \\
& d_{i 0}=\frac{\bar{d}_{i}+\underline{d}_{i}}{2}, \quad \delta_{i}=\frac{\bar{d}_{i}-\underline{d}_{i}}{2}, \quad i=1,2 \\
& \theta_{00}=\frac{\bar{\theta}_{0}+\underline{\theta}_{0}}{2}, \delta_{0}=\frac{\bar{\theta}_{0}-\underline{\theta}_{0}}{2}
\end{aligned}
$$

と表現される.このとき式(23)は

$$
\begin{aligned}
\dot{\overline{\boldsymbol{x}}}_{0}(t) & =\left(\bar{A}_{20}+D \bar{\Delta} E\right) \overline{\boldsymbol{x}}_{0}(t)+\boldsymbol{b}_{2} u_{2}(t) \\
\bar{A}_{20} & =\left[\begin{array}{cccc}
-d_{10} & 0 & 0 & 0 \\
\frac{m_{1}}{m_{2}} \theta_{00} q & -\left(d_{20}-q\right) & 0 & 0 \\
1 & 0 & 0 & 0 \\
0 & 1 & \theta_{00} q & q
\end{array}\right] \\
\bar{\Delta} & =\operatorname{diag}\left[\frac{\Delta_{1}}{\delta_{1}}, \frac{\Delta_{2}}{\delta_{2}}, \frac{\Delta_{0}}{\delta_{0}}, \frac{\Delta_{0}}{\delta_{0}}\right] \\
D & =\left[\begin{array}{llll}
0 & 0 & 1 & 0 \\
1 & 0 & 0 & 0 \\
0 & 0 & 0 & 0 \\
0 & 1 & 0 & 0
\end{array}\right], \quad E=\left[\begin{array}{cccc}
\frac{m_{1}}{m_{2}} q \delta_{0} & 0 & 0 & 0 \\
0 & 0 & q \delta_{0} & 0 \\
\delta_{1} & 0 & 0 & 0 \\
0 & -\delta_{2} & 0 & 0
\end{array}\right]
\end{aligned}
$$

となり，構造的不確かさ $\bar{\Delta} \in \mathbb{R}^{4 \times 4}$ は

$$
\|\bar{A}\| \leq 1
$$

を満たす，不確かさをもつ式(27)のシステムのロバスト安 定性に関して，第3章の定義で述へた一次安定性を用いる と，つぎの補助定理を得る. 


\section{補助定理 2}

不確かさ $\bar{\Delta} \in \mathbb{R}^{4 \times 4}$ を除いた式(27)の線开時不変系

$$
\dot{\bar{x}}_{0}(t)=\bar{A}_{20} \overline{\boldsymbol{x}}_{0}(t)+\boldsymbol{b}_{2} u_{2}(t)
$$

が可制御であるための必要十分条件は

$$
q \neq d_{20}
$$

である.このとき, 式(28)の不確かさをもつ式(27)のシス テムが定数ゲインの状態フィードバックで二次安定化可能 であるための必要十分条件は，適当な定数 $\varepsilon>0$ に対して， つぎのリカッチ不等式

$$
\bar{A}_{20}^{T} P+P \bar{A}_{20}-\varepsilon P \boldsymbol{b}_{2} \boldsymbol{b}_{2}^{T} P+P D D^{T} P+E^{T} E<0
$$

が正定解 $P>0$ をもつことである. また二次安定化を達成 する補償器の一つは, この正定解 $P \in \mathbb{R}^{4 \times 4}$ と正の定数 $\varepsilon \in \mathbb{R}$ を用いて次式で与えられる.

$$
u_{2}(t)=f_{2} \bar{x}_{0}(t), \quad f_{2}=-\frac{\gamma}{2} \varepsilon b_{2}^{T} P(\gamma \geq 1)
$$

証明: 可制御については文献(12)と同様であり，二次 安定化については文献(21)より明らかであるため省略 する.

以上の結果をまとめると, 式(5)と式(6)のシステム に対するロバス卜安定化補償器に関して，次の定理は その補償器の存在条件と簡単な設計法を与える.

\section{定理 3}

式(13)のフィードバック補償器を考える. ただし設 計パラメータ $q \in \mathbb{R}$ は, 式(14)と式(18) と式(30)を満 たすように選ぶ. 適当な定数 $\varepsilon>0$ に対して, 式(31) のリカッチ不等式の正定解 $P>0$ が存在寸れば, 式(7) を満たす任意の速度減衰係数と任意の初期状態に対し て式(5)と式(6)のシステムの原点安定，すなわち状 態 $x_{1}(t) \in \mathbb{R}^{2}$ と $x_{2}(t) \in \mathbb{R}^{4}$ を全て零に収束させるフィ 一ドバック補償器 $u_{2}(t) \in \mathbb{R}$ は存在し，そのひとつは 式(32)のフィードバックゲイン $f_{2} \in \mathbb{R}^{4}$ を用いて次式 で与えられる。

$$
u_{2}(t)=f_{2} \bar{x}_{2}(t)\left(=f_{2} \Lambda(t) x_{2}(t)\right)
$$

証明: 式(33)の補償器を用いると, 閉ループシステム はつぎのように表せる.

$$
\dot{\bar{x}}_{2}(t)=\left(\bar{A}_{2}+b_{2} f_{2}\right) \overline{\boldsymbol{x}}_{2}(t)+\Delta_{A}(t) \overrightarrow{\boldsymbol{x}}_{2}(t)
$$

補助定理 2 より $\left(\bar{A}_{2}+b_{2} f_{2}\right) \in \mathbb{R}^{4 \times 4}$ は安定行列であり，
時変要素 $\boldsymbol{A}_{A} \in \mathbb{R}^{4 \times 4}$ は式(22)を満たすため, 補助定理 1からシステムは大域的ロバスト安定である.

注 1 ) 式(31)のリカッチ不等式は，与えられた定数 $\varepsilon>0$ に対してLM I (線形行列不等式) 問題 (25)，に帰 着できるため, ロバスト安定化補償器の存在条件と式 (33)の補償器の設計は容易である.

注2）式(20)の座標変換は，機体座標系における横方 向速度 $v$ と位置 $z_{2}$ に時変な重みを掛けている. したが ってこの座標変換により, まず飛行船の横方向の位置 と速度を優先的に零に収束させ，その後，姿勢角度 · 角速度, 進行方向の位置·速度の順で零に収束させる. 本章で提案した制御系の構成図を図 2 に示寸。

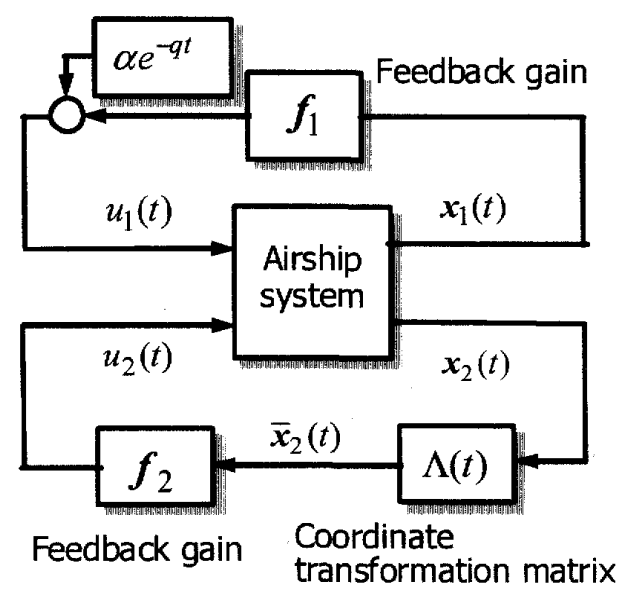

Fig.2 Block diagram of robust feedback control system for airship system (in the case of $m_{1}=m_{2}$ )

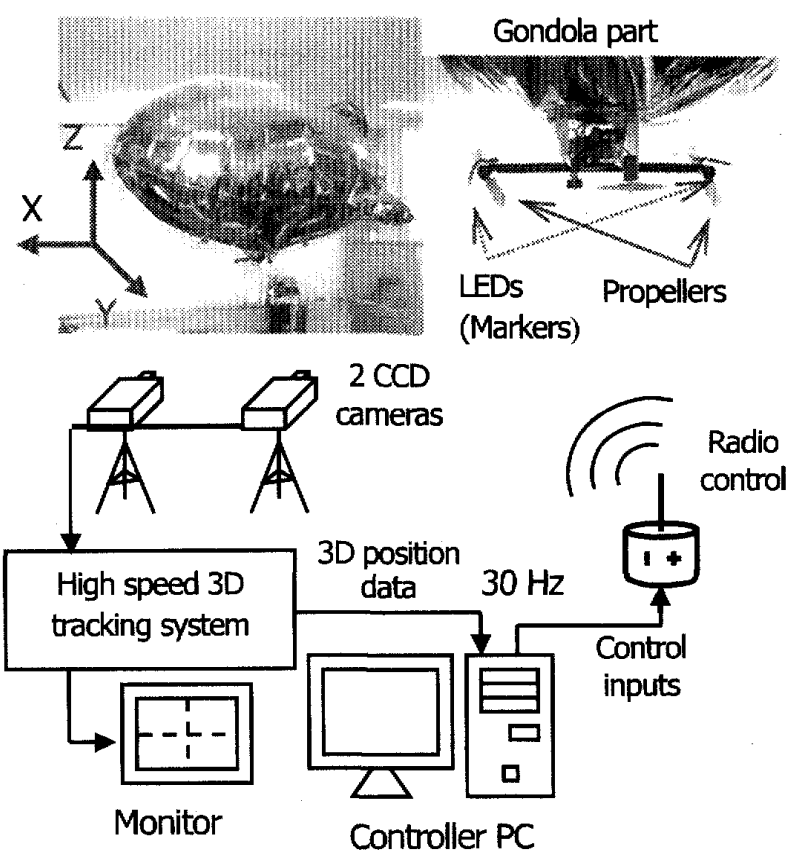

Fig.3 Radio control system of blimp in experiments 
本論文で提案する設計法を以下にまとめる.

\section{《設計法のまとめ》}

1. 速度減衰係数の実測データから, $\left[d_{3}, \bar{d}_{3}\right]$ や式(26) $の\left[d_{i 0}, \delta_{i 0}\right], i=1,2$ など，係数の範囲や不確かさに 関するパラメータを求める.

2. 1 で求めた $\left[\underline{d}_{3}, \bar{d}_{3}, d_{20}\right]$ を用いて, 設計パラメータ $\left[k_{1}, k_{2}, q, \alpha\right] \in \mathbb{R}^{4}$ を式(14) と式(18)と式(30)を 満たすように選び，式(13)の回転方向成分に関す るフィードバック補償器 $u_{1}(t)$ を得る.

3. 適当な定数 $\varepsilon>0$ に対して, 式(31)のリカッチ不 等式の正定解 $P>0$ 在求め, 式(32)のフィードバッ クゲイン $f_{2} \in \mathbb{R}^{4}$ を計算し, 式(33)の並進方向成分 に関するフィードバック補償器 $u_{2}(t)$ を得る.

\section{5. 実験}

本章では，図 3 の小型無線飛行船（全長 $1[\mathrm{~m}]$, 直径 $0.5[\mathrm{~m}]$ ）を用いた屋内飛行実験の結果を示す，図 3 に 示すように, この小型飛行船は, 機体下部に取り付け られたゴンドラ部の 2 つのプロペラで駆動される. ゴ ンドラ部に搭載した 2 つのLE を地上の 2 台の CCD カメラにより撮影し, 飛行船の位置と姿勢をリアルタ イムで計測し、コンピュータで制御入力を計算し, 無 線でゴンドラ部の $2 つ$ つ゚ロペラに制御人力を $30 \mathrm{~Hz}$ で無線送信するフィードバック制御装置を製作した. 飛行船のパラメータは

$$
\begin{aligned}
& {\left[m_{1}, m_{2}, m_{3}\right]} \\
& =\left[0.072[\mathrm{~kg}], 0.074[\mathrm{~kg}], 0.005\left[\mathrm{kgm}^{2}\right]\right]
\end{aligned}
$$

であり，速度減衰係数の実測データは

$$
\begin{aligned}
& 0.033[1 / s] \leq d_{1} \leq 0.099[1 / s] \\
& 0.023[1 / s] \leq d_{2} \leq 0.063[1 / s] \\
& 0.12[1 / s] \leq d_{3} \leq 0.36[1 / s]
\end{aligned}
$$

であった．このとき式(26)からパラメータ範囲は

$$
\begin{gathered}
d_{i}=d_{i 0}+\Delta_{i},\left|\Delta_{i}\right| \leq \bar{\delta}_{i} d_{i 0}, \quad i=1,2,3 \\
{\left[d_{10}, d_{20}, d_{30}\right]=[0.066,0.043,0.24]} \\
{\left[\bar{\delta}_{1}, \bar{\delta}_{2}, \bar{\delta}_{3}\right]=[0.50,0.47,0.50]}
\end{gathered}
$$

と表される. システムのロバスト安定性を検証するた め数值シミュレーションを行う. 数值シミュレーショ ンでは速度減衰係数のパラメータ範囲を式(37)より少 し大きめに与え,つぎのような場合について考察した.

$$
\begin{aligned}
& \underline{d}_{i}\left(=d_{i 0}-0.5 d_{i 0}\right) \leq d_{i} \leq \bar{d}_{i}\left(=d_{i 0}+0.5 d_{i 0}\right), \\
& i=1,2,3
\end{aligned}
$$

定理 3 により，ロバスト安定化補償器を設計すると

$$
\left\{\begin{array}{l}
{\left[k_{1}, k_{2}, q, \alpha\right]=[0.320,0.286,0.100,0.0920]} \\
f_{2}=[0.949,-1.79,0.896,0.299]
\end{array}\right.
$$

を得る. シミュレーションの際の初期状態は以下のと おりである.

$$
\begin{aligned}
& {[x(0), y(0), \theta(0)]=[-0.6[\mathrm{~m}], 0.6[\mathrm{~m}], 1.75[\mathrm{rad}]]} \\
& {[u(0), v(0), r(0)]=[0.0[\mathrm{~m} / \mathrm{s}], 0.0[\mathrm{~m} / \mathrm{s}], 0.0[\mathrm{rad} / \mathrm{s}]]}
\end{aligned}
$$

まず速度減衰係数が公称值 $\left(d_{i}=d_{i 0},(i=1,2,3)\right)$ の場合のシミュレーション結果 (以降,「シミュレーシ ヨン1」と呼ぶ) を図 4〜8 に示す．図 4 は飛行船重 心の軌跡，図 5 注飛行船の状態（位置と姿勢）の時間 応答, 図 6 は残りの状態 (速度と角速度) の時間応答, 図 7 と 8 注制御入力の時間応答を示す. またロバスト 性能を検証するため, 速度減衰係数方式(38)の下限值 $\left(d_{i}=\underline{d}_{i},(i=1,2,3)\right)$ の場合のシミュレーション結 果 (以降,「シミュレーション 2 と呼ぶ) を図 9 と 図 10 に示し, 速度減衰係数が式(38)の上限值 $\left(d_{i}=\bar{d}_{i}\right.$, $(i=1,2,3)$ ) の場合（以降,「シミュレーション3」 と呼ぶ) のシミュレーション結果を図 11 と図 12 に示 す.これらの図から，提案したロバストフィードバッ ク補償器は, 飛行船の重心位置を指定された原点に, かつ姿勢角を零にすばやく滑らかに収束させ，優れた 定点滞空特性が得られることを確認できる，とくに図 5 と 6 より, 本手法を用いればこの座標変換の効果に より，まず $\mathrm{Y}$ 軸方向の位置が優先的にゼロに収束し， その後, 姿勢角度, $\mathrm{X}$ 軸方向の位置が零に収束するこ とがわかる. その結果, 滑らかで振動もなく, 車の車 庫入れのような軌跡を与えており, 最後に飛行船シス テムの全ての状態は希望どおり需に収束していること がわかる.さらに図 9〜12のように，速度減衰係数に 不確かさが存在しても，安定性が保証されており，本 手法の有用性が示されている.

本手法の実用性を実証するため, 屋内飛行実験を行 った. 実験では式(39)のコントローラを用いて，初期 状態は式(40) と同じ条件で行った。図 13 は「実験」 における飛行船重心の軌跡, 図 14 は飛行船の動きの 連続写真, 図 15 は飛行船システムの状態（位置と姿 勢）の時間応答，図 16 は残りの状態（速度と角速度） の時間応答，図 17 と 18 は制御入力の時間応答を示す. 図 4〜8 のシミュレーション結果と比較すると，y方 向成分に関しては実験結果の方が行き過ぎ量は少し小 さく応答も早く収束している. この行き過ぎ量の差異 の原因としてつぎの 2 点が考えられる. 第一の原因は 並進方向成分のサブシステム $\Sigma_{2}$ の制御入力 $\tau_{u}(t)$ の 
飽和である. 図 7 と図 17 を比較すると，実験におけ る制御入力 $\tau_{u}(t)$ は $0 \leq t \leq 1[s]$ の間，プロペラ用モー タへの入力值が設定された上限值で飽和しており，シ ミュレーション結果より小さい. その結果, 実験結果 の方が $\mathrm{y}$ 方向の行き過ぎ量が小さくなったと思われる. 第二の原因はピッチなど振動現象である. 実験ビデオ (動画) で確認したところ, 本飛行実験時においてピ ッチの振動があり,その結果図 16 のように速度が振動 し，実験結果の方が行き過ぎ量が小さくなったと考え られる. これらの点以外は $\mathrm{x}$ 方向, $\mathrm{y}$ 方向および回転 成分ともに，波形や大きさなざ応答の特徽は実験とシ ミュレーションでほぼ一致しており, 本手法の赛用性 と有用性が実験にて実証された。

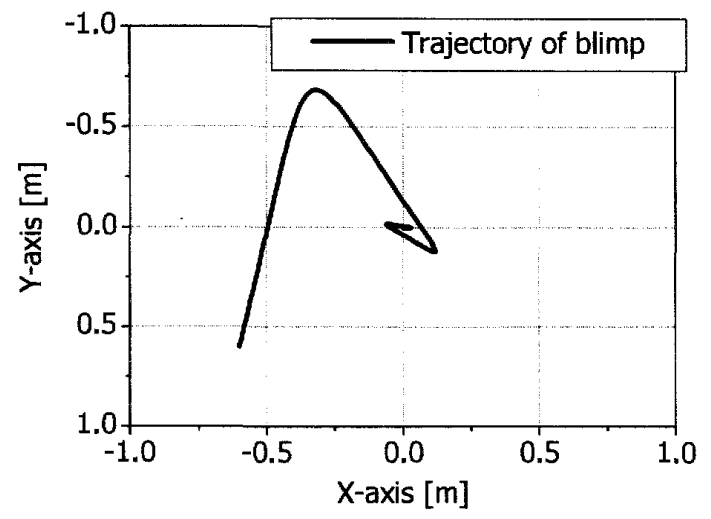

Fig.4 Trajectory of blimp in simulation 1

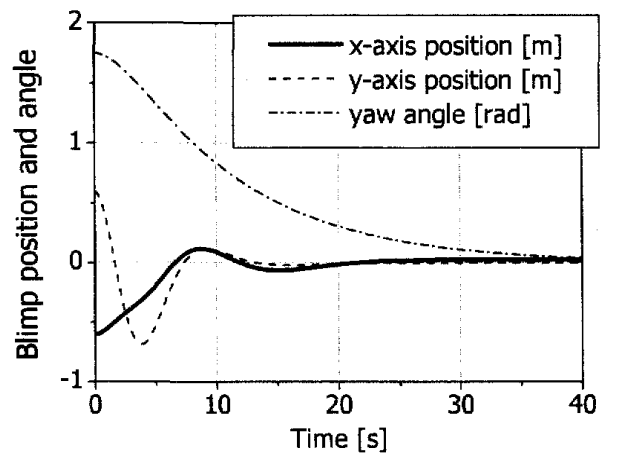

Fig.5 Time responses of states in simulation 1

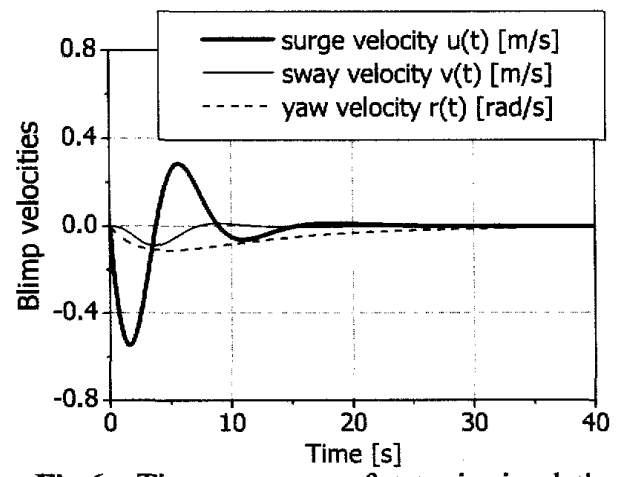

Fig.6 Time responses of states in simulation 1

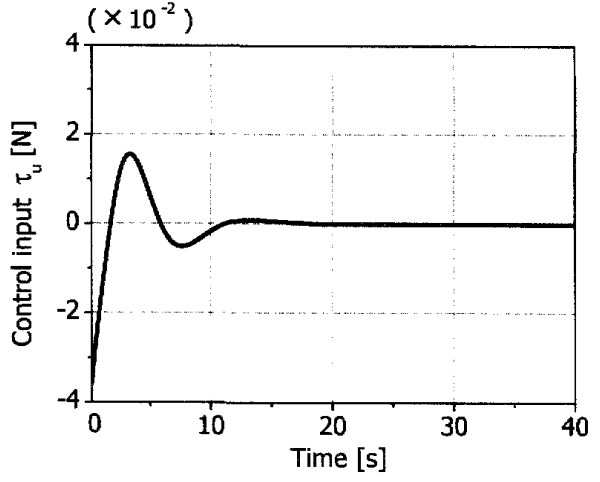

Fig.7 Time response of control input in simulation 1

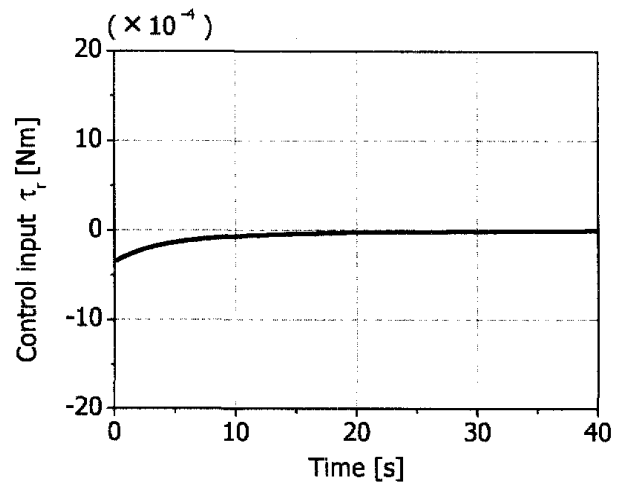

Fig.8 Time response of control input in simulation 1

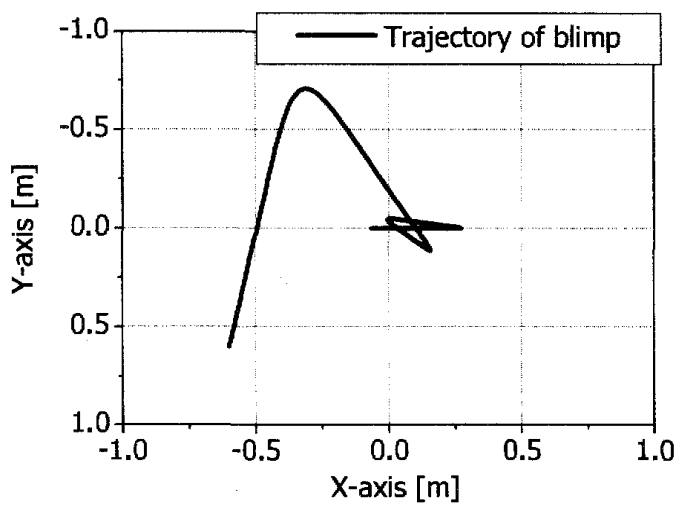

Fig.9 Trajectory of blimp in simulation 2

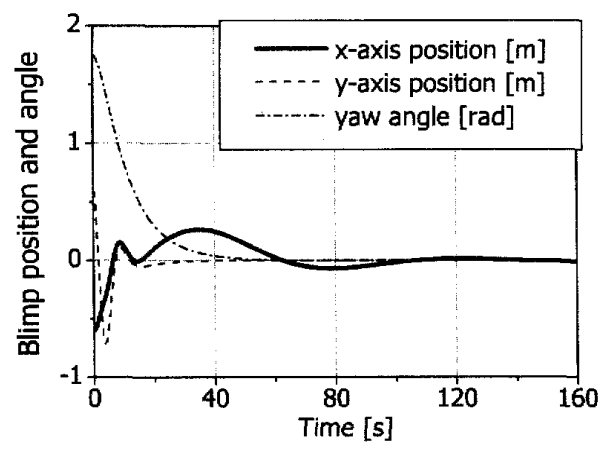

Fig.10 Time responses of states in simulation 2 


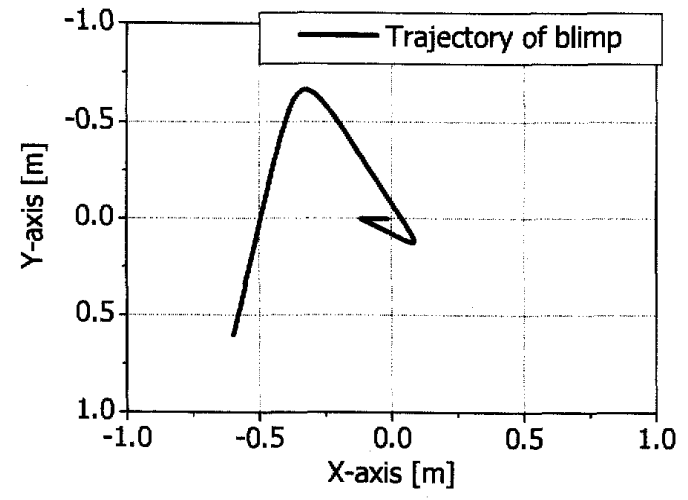

Fig.11 Trajectory of blimp in simulation 3

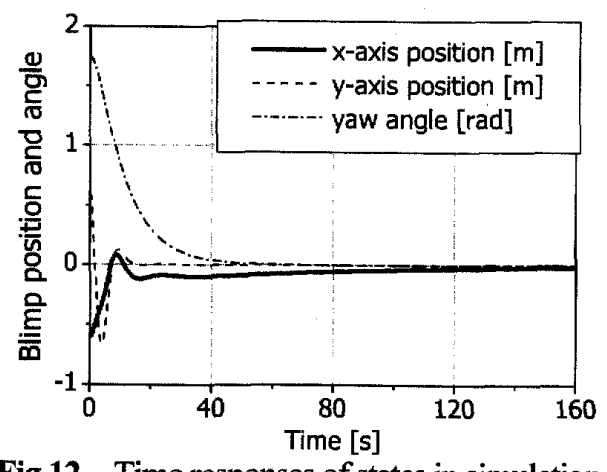

Fig.12 Time responses of states in simulation 3

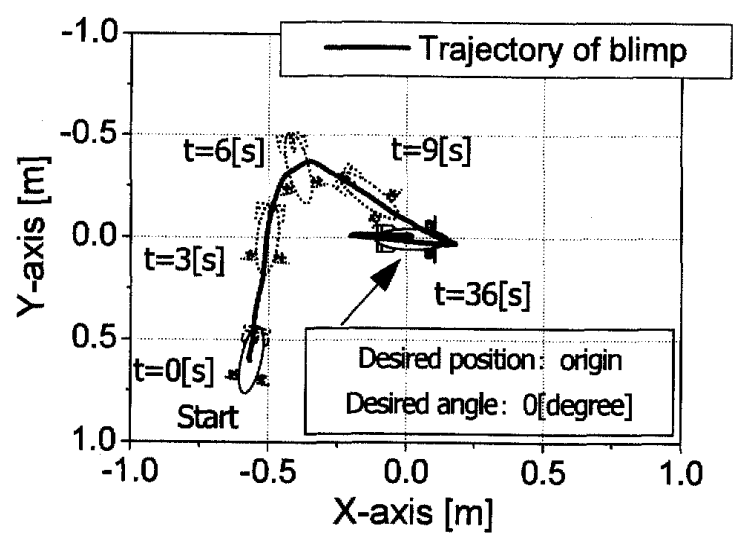

Fig.13 Trajectory of blimp in flight experiment

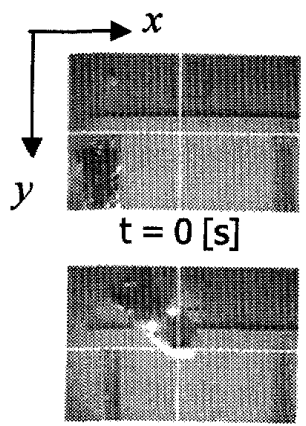

$t=9[s]$

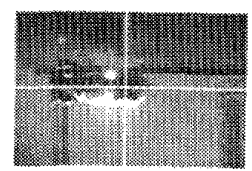

$\mathrm{t}=24[\mathrm{~s}]$

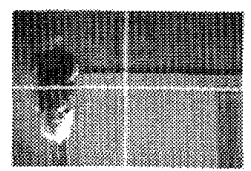

$\mathrm{t}=3[\mathrm{~s}]$
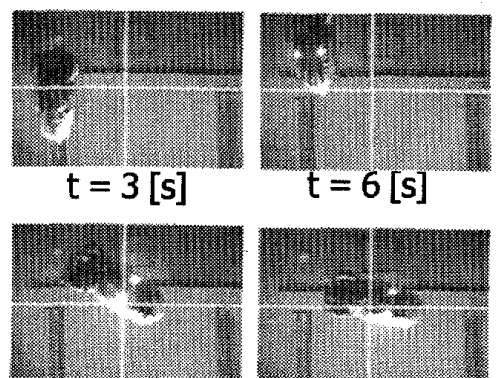

$\mathrm{t}=\mathrm{12}[\mathrm{s}]$
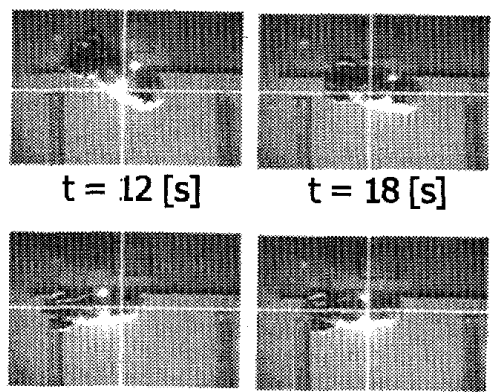

$\mathrm{t}=18[\mathrm{~s}]$

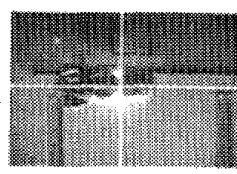

$\mathrm{t}=36[\mathrm{~s}]$

Fig.14 Sequence photographs of blimp motion in flight experiment

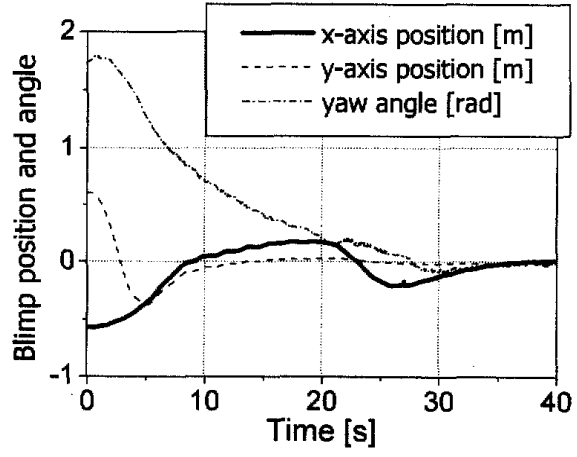

Fig.15 Time responses of states in flight experiment

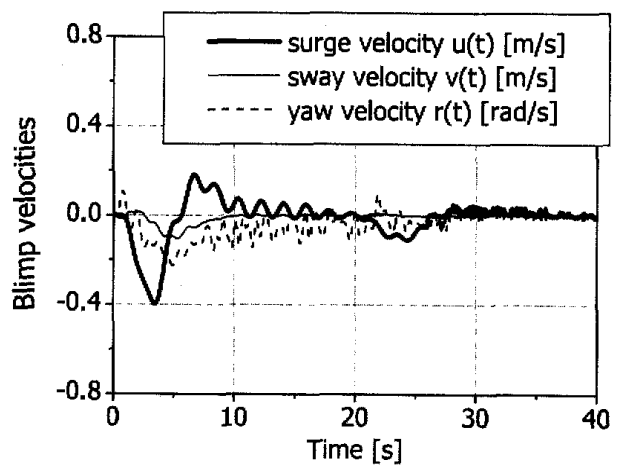

Fig.16 Time responses of states in flight experiment

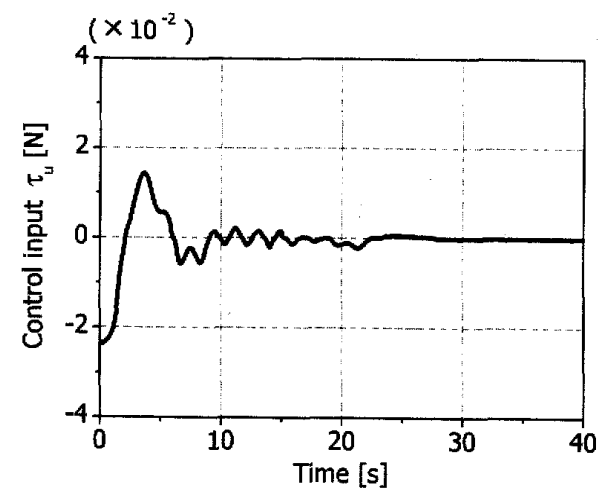

Fig.17 Time response of control input in flight experiment

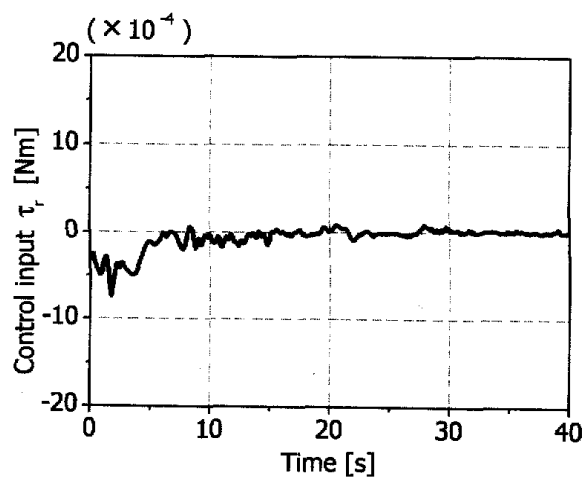

Fig.18 Time response of control input in flight experiment 


\section{6. 結 誊}

本論文では，速度减衰係数などに不確かさをもつが 範囲は既知である劣駆動飛行船システムのロバスト安 定化問題を考え，座標変換と 2 次安定化制御に基づい た新しい手法で，大域的ロバスト安定化制御系の設計 法を提案した．これらの設計問題を時変で滑らかな座 標変換により，ある線形時不変システムの安定化問題 に帰着させ設計法を簡単化した. 最後に，小型飛行船 を用いて自律飛行制御実験を実施し，本手法の有用性 を飛行実験により害証した。今後の課題は，風外乱の 抑制問題，過渡応答におけるシステムの状態や制御入 力值を最適化する最適制御系への拡張である，また， 本論文では慣性に関する係数 $\left(m_{i}, i=1,2,3\right)$ に不確 かさをもつ場合を考慮しておらず，例えば式(13)の補 償器で用いている非線形項の消去などでモデル化誤差 を起こしやすい，そこで慣性倸数の不確かさに対する ロバスト制御問題も重要な課題である．野外飛行など の観点からピッチ・ロールなどの変化を抑え 3 次元空 間での位置や姿勢も安定化するような飛行船システム の制御系設計も実用上重要な課題である.

査読者の方々から論文の記述や今後の課題などに 関して有用なご意見をいただきました，本研究の成果 の一部は科学研究費補助金基盤研究(B)(19360191)の研 究助成によるものである.ここに感謝の意を表します.

\section{文 献}

(1) Funk, P., Lutz, T. and Wagner, S., Experimental Investigations on Hull-Fin Interferences of the LOTTE Airship, Aerospace Science and Technology, Vol. 7, (2003), pp.603-610.

(2) Khoury, G.A. and Gillett, J.D., Airship Technology, Cambridge Aerospace Series 10, (1999), Cambridge University Press.

(3) Shimizu, T., Japanese Stratospheric Platform (SPF) Airship Project Progress, Proceedings of the fifth Stratospheric Platform Systems Workshop, (2005), pp.15-22.

(4) Umeno, M. et al., R\&D Plan and Research Results in 2007 on Japanese Ministry of Internal Affairs and Communications, Strategic Information and Communication R\&D Promotion Programme, Annual Report of Fire Research Laboratory, Vol. 37, (2008), pp.53-61.

(5) Fossen, T.I., Marine Control Systems, (2002), Marine Cybernetics.

(6) Reyhanoglu, M., Exponential Stabilization of an Underactuated Autonomous Surface Vessel, Automatica, Vol.33, (1997), pp.2249-2254.

(7) Mita, T., Introduction to Nonlinear Control Theory - Skill Control of Underactuated Robots -, (2000), Shoko-do.

(8) Brockett, R.W., Differential Geometric Control Theory, (1983), pp.181-191, Boston Birkhauser.

(9) Jiang, Z.P., Global Tracking Control of Underactuated
Ships by Lyapunov's Direct Method, Automatica, Vol. 38, (2002), pp.301-309.

(10) Mazenc, F., Petersen, K. and Nijimeijer, H., Global Uniform Asymptotic Stabilization of an Underactuated Surface Vessel, IEEE Trans. on Automatic Control, Vol. 47, (2002), pp.1759-1762.

(11) Pettersen, K.Y. and Fossen, T., Underactuated Dynamic Positioning of a Ship - Experimental Results, IEEE Trans on Control Systems Technology, Vol. 8, No.5, (2000), pp.856-863.

(12) Yamada, M. and Tomizuka, M., Global Exponential Stabilization of an Underactuated Nonholonomic Airship, Transactions of the Society of Instrument and Control Engineers, Vol.45, No.2, (2009), pp.99-104.

(13) Yamada, M., Hybrid Control of Nonholonomic Chained Systems (Review), Journal of the Society of Instrument and Control Engineers, Vol.45, No.7, (2006), pp.582-588.

(14) Yamada, M., Sato, S. and Tomizuka, M., Global Exponential Stabilization of an Underactuated Airship Without Measurement of Velocities and Flight Experiments, Transactions of the Japan Society of Mechanical Engineers, Series- $C$, Vol.75, No.754, (2009), pp.1671-1679.

(15) Nesic, D., Teel, A.R. and Kokotovic, P.V., Sufficient Conditions for Stabilization of Sampled-Data Nonlinear Systems via Discrete-Time Approximation, System and Control Letters, Vol.38, (1999), pp.259-270.

(16) Nesic, D., Teel, A.R. and Sontag, E.D., Formulas Relating $\mathrm{KL}$ Stability Estimates of Discrete-Time and Sampled-Data Nonlinear Systems, System and Control Letters, Vol.38, (1999), pp.49-60.

(17) Nesic, D. and Grune, L., Lyapunov Based Continuous-Time Nonlinear Controller Redesign for Sampled-Data Implementtaion, Automatica, Vol.41, (2005), pp.1143-1156.

(18) Nesic, D. and Grune, L., Receding Horizon Control Approach to Sampled-Data Implementation of Continuous-Time Controller, System and Control Letters, Vol.55, (2006), pp.660-672.

(19) Do, K.D., Jiang, Z.P. and Pan, J., Robust Adaptive Path Following of Underactuated Ships, Automatica, Vol. 40, (2004), pp.929-944.

(20) Do, K.D. and Pan, J., Global Robust Adaptive Path Following of Underactuated Ships, Automatica, Vol. 42, (2006), pp.1713-1722.

(21) Petersen, I.R., A Stabilization Algorithm for a Class of Uncertain Linear Systems. System and Control Letters, Vol.8, (1987), pp.351-357.

(22) Petersen, I.R. and Hollot, C.V., A Riccati Equation Approach to the Stabilization of Uncertain Linear Systems. Automatica, Vol.22, No.4, (1986), pp.397-411.

(23) Arnold, V.I., Geometrical Methods in the Theory of Ordinary Differential Equations, (1983), Springer, New York.

(24) Slotine, J. J. E. and Li, W., Applied Nonlinear Control, (1991), Prentice Hall, pp.115.

(25) Iwasaki, T., LMI and Control, (1997), Shoko-do. 